\title{
Influence of indole butyric acid (IBA) concentrations on air layerage in guava (Psidium guajava L.) cv. Sufeda
}

Syed Abdul Qadir Gilani ${ }^{1}$, Kamran Shah ${ }^{1,2^{*}}$, Imran Ahmed ${ }^{1}$, Abdul Basit $^{1}$, Muhammad Sajid ${ }^{1}$, Aneela Shah Bano ${ }^{1}$, Gulshan Ara ${ }^{3}$ and Umaira Shahid ${ }^{4}$

1. Department of Horticulture, The University of Agriculture Peshawar-Pakistan

2. College of Horticulture, Northwest Agriculture and Forestry University, Yangling 712100, Shaanxi-China

3. Institute of Biotechnology and Genetic Engineering, The University of Agriculture, Peshawar-Pakistan

4. Agriculture Research Institute Tarnab, Peshawar-Pakistan

*Corresponding author's email: kamranshah801@gmail.com ; kamranshah801@aup.edu.pk

Citation

Syed Abdul Qadir Gilani, Kamran Shah, Imran Ahmed, Abdul Basit, Muhammad Sajid, Aneela Shah Bano, Gulshan Ara and Umaira Shahid. Influence of indole butyric acid (IBA) concentrations on air layerage in guava (Psidium guajava L.) cv. Sufeda. Pure and Applied Biology. Vol. 8, Issue 1, pp355-362. http://dx.doi.org/10.19045/bspab.2018.700194

\begin{tabular}{llll}
\hline \hline Received: 27/08/2018 & Revised: 22/10/2018 & Accepted: 02/11/2018 & Online First: 03/12/2018 \\
\hline \hline
\end{tabular}

\section{Abstract}

Air layering is the expedient way to get more number of plants however, root initiation in cuttings is a key success in case of Guava. Indolebutyric acid (IBA) hormone induces rooting but its appropriate concentration and response of guava cv. Sufeda was unknown. This experiment was carried out at Horticultural Research Farm, The University of Agriculture Peshawar, during 2016. One year old healthy branches of guava were selected and wounded by complete removal of 2 inches bark just below the bud for rooting. These wounds were covered with soil media containing different concentrations of IBA hormone, wrapped with plastic and tied at both ends. The air layered plants detached after rooting were shifted to polythene bags and were kept in plastic tunnel to maintain its humidity. Different concentrations of IBA i-e T1 (50 ppm), T2 (100 ppm), T3 (150 $\mathrm{ppm}), \mathrm{T} 4(200 \mathrm{ppm})$ and control (T0) were applied. According to data analysis layers treated with $150 \mathrm{ppm}$ of IBA (T3) was successful. Data recorded in control was minimum as compared to other treatments. We concluded that, the Guava cv. Sufeda air layered during monsoon season treated with $150 \mathrm{ppm}$ IBA solution gives best results.

Keywords: Air layerage; Growth; Guava; IBA concentrations; Rooting

\section{Introduction}

Guava botanical name (Psidium guajava L.) belongs to the family Myrtaceae, and a tropical region plant. It is native to Central America, Northern South America and Mexico. It is an important fruit with a very high nutritive value, pleasing smell and good tastes, makes digestion fast, rich in nutrients and vitamin C. It survives well due to its hardy nature even if it is ignored. It is believed that Guava is grown in subcontinent since $17^{\text {th }}$ century it can be grown in different climatic and edaphic conditions. The important fruit giving crops twice a year is widely grown in all four provinces of Pakistan. It is placed on $4^{\text {th }}$ position with regards to Guava production among the fruits being grown all over the country. It has been 
reported that Guava is grown over an area of 60.8thousand hectares with total production of 461.4 thousand tones [1].

Guava propagation through seed does not produce true to type plants while clonal propagation is successful in producing true to type plants. Maqbool and Khan [2] reported that guava is commercially propagated from seeds in Pakistan. It is mostly propagated from seed. However, plants propagated through seeds are not true to type and takes longer time to reach to bearing stage when compared to vegetative propagation. There is no as such standard variety of this fruit in the country.

There are several vegetative methods used for multiplication of different tree species but air layering is widely used as a method of propagation, where the formation of roots from cuttings is slow [3]. The use of growth regulators to enhance rooting for air layering is well documented for guava and is reported to be the most successful method [4] noted that members of the genera Abies, Picea, Pinus, Larix, Pseudotsuga, Chamaecyparis, and Cryptomeria had all been observed to reproduce by layering. Amending growing media with fertilizer can promote seedling and branching growth, establishment and survival of air layered branches [5]. Air layering is reported to have yielded good results. Air layering with the help of growth regulators stimulated root primordial in air layers of fruit plants [6]. However, the survival percentage of rooted layers in open conditions is very poor [7], and is not achieving up to an expectation of the demand at cheaper rate with high establishment and survival percentage. To facilitate better percentage of establishment and survival of rooted layers, a poly-house nursery condition is the substitute to an open nursery conditions.

Among the vegetative methods of guava propagation, air layering with the help of growth regulators is a successful method of propagation [6]. Exogenous application of IBA speeds up the rate of rooting, increases root percentage and number of roots per plant. Growth regulators like IBA stimulate cell division, cell elongation and metabolic activity at the place where incision is made. It might be because the natural Auxins respond to the wounded area due to which rooting is initiated. The differences in rooting percentage, better root character and survival of guava air layer may be also attributed to the varying in weather conditions such as temperature, relative humidity and rainfall [7]. So in the light of above literature, clues, and information, we conducted current experiment to study the effect, influence, or responses of the various concentrations of IBA on rooting performance of Guava cv. Sufeda, propagated through air layering and find out appropriate IBA concentration which could benefit local Guava growers of Pakistan.

\section{Materials and methods Experimental site}

The experiment, "effect of IBA concentrations on rooting performance of Guava cv. Sufeda propagated through air layerage" was laid out at Horticultural Research Farm Malakander, The University of Agriculture Peshawar, during the month of August, 2016.

Experimental design and treat combination

Randomized Complete Block Design was applied with factorial arrangements having 4 treatments and the treatments were replicated three times.

Fresh, healthy, disease free, 1 year old branches were selected. In order to initiate rooting in guava, branches were wounded by complete removal of bark 2 inches just below the bud. These wounds were covered with soil media containing different concentrations of IBA hormone and wrapped with plastic, and tied at both ends. The air layered plants detached after rooting were 
shifted to polythene bags and were kept in plastic tunnel to maintain its humidity. Different level of IBA concentrations were applied to each treatment: 0 (control), 50, 100, 150, 200 ppm. Number of days to rooting, number of sprouts per plant, number of leaves per plant was counted and fresh root weight (g) was measured using Ohaus digital balance (Ohaus Scale Corp. Florham Park, NJ, USA) after harvesting the samples were placed in Post-Harvest laboratory, Department of Horticulture, The University of Agriculture Peshawar, Pakistan. The samples were then placed in oven for 24 hours in $70{ }^{\circ} \mathrm{C}$, and were weighted again for calculating the dry weight (g) using same digital balance. Root length $(\mathrm{cm})$ was measured using standard Vernier scale. Percent rooting were calculated according to [8], however for chlorophyll and carotenoid contents the procedure described by $[9,10]$ were followed.

\section{Statistical analysis}

The data recorded was subjected to analysis of variance (ANOVA) suitable for randomized complete block design using statistics 8.1 software package. Significant findings were tested by least significant difference (LSD). Data shown as SEM \pm SE. $\mathrm{P}<0.05$ was considered significant [11].

\section{Results and discussion}

\section{Percent rooting (\%)}

Results for rooting $46.6 \%, 63 \%, 86 \%$, and $36 \%$ through air layering in guava for different concentrations of IBA 50 ppm, 100 ppm, 150 ppm, 200 ppm respectively were observed (Figure 1). Results also showed that rooting percentage for concentration of $\mathrm{T} 3$ $(86 \%)$ was more as compared to other concentrations as well as T0 control (3\%).

This result is in accordance with [8], who revealed that maximum rooting of air layering was observed with IBA concentration $\quad 10,000 \quad \mathrm{ppm} \quad(76.08 \%)$, followed by 7500 ppm (70.96\%). However, minimum rooting percentage was observed in control $(31.74 \%)$. The reason could be the auxin application has been reported to stimulate cambial activity, thus resulting in mobilization of stored food material to the root initiation site. Both synthetic and natural auxins like IAA, IBA and NAA when applied exogenously on stem cuttings increases the formation of pre-existing roots primordial, which generally increases the number of roots per cut that further helps in its sprouting and growth as stated by [12]. The improved hydrolytic activity due to IBA application may also be responsible for the increased percentage of roots in cuttings. More carbohydrate and less nitrogen have been found to favor root development [13].

\section{Number of days to root}

Data for number of days to root appearance is presented in (Figure 1). The data showed that minimum days (15) to root appearance were taken by T4 (treated with IBA 200 ppm) however, maximum days (39) were taken by T0 (control). This result revealed that maximum concentration of IBA speeded up rooting in air layering in guava. These results are in accordance with [14], who reported that the response of IBA with increasing concentration might be due to the activity of auxin at cambial that may be adequate for initiating root primordia early. Other reason could be the better utilization of reserved carbohydrates in the hardwood, with the application of exogenous auxin, and the auxin concentration enhanced in the cell which increased cell division that further speed up callus formation in the cuttings as reported by $[12,14]$ in plum. Similar reports were also stated by [15] in stevia and [16] in grapes. 


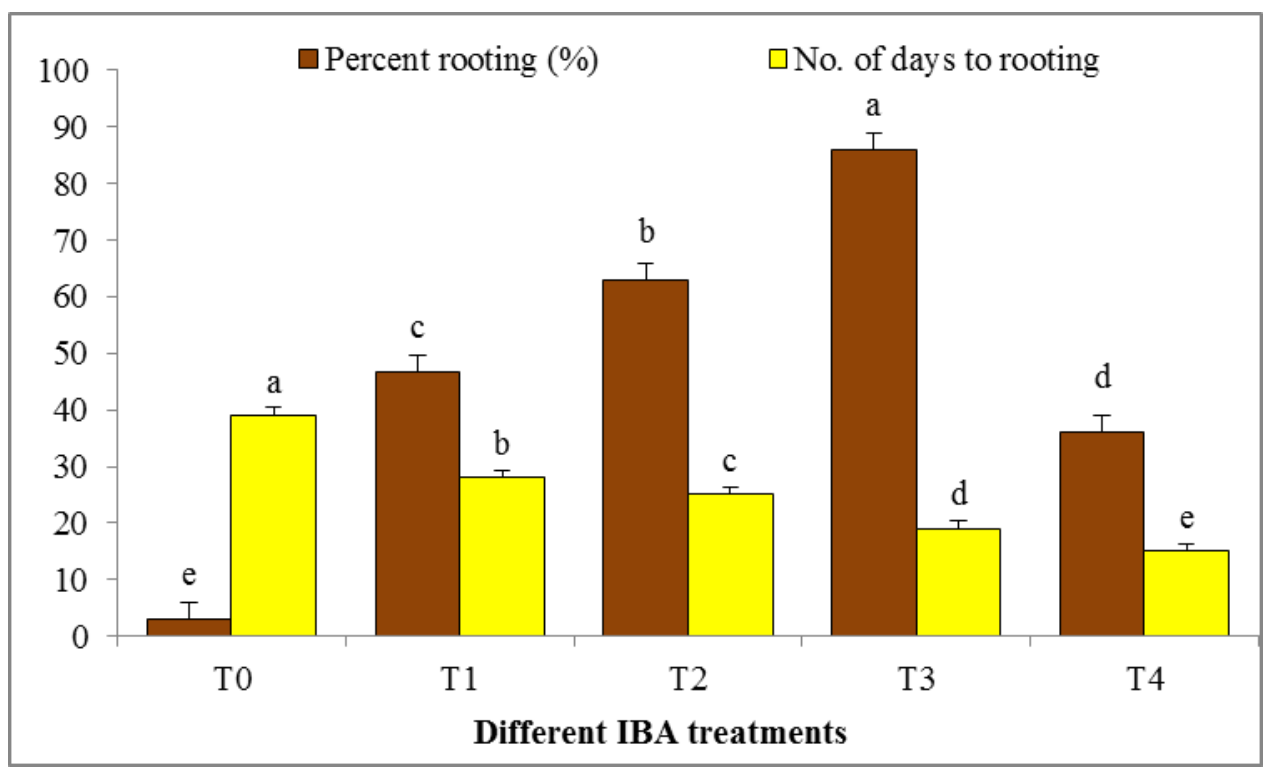

Figure 1. Effect of different IBA concentrations on percent rooting i-e $(86 \%)$ and No. of minimum days (15) to rooting of Guava cv. Sufeda propagated through air layering Number of sprouts per plant

According to the results observed for number of sprouts per plant the maximum mean value for fresh sprouts were reported in T3 (7) and less number of sprouts per plant in Control treatment T0 (2) (Figure 2). This is because higher concentration of IBA increases primary and secondary rooting which favors in producing new sprouts in Guava air layers $[7,8]$.

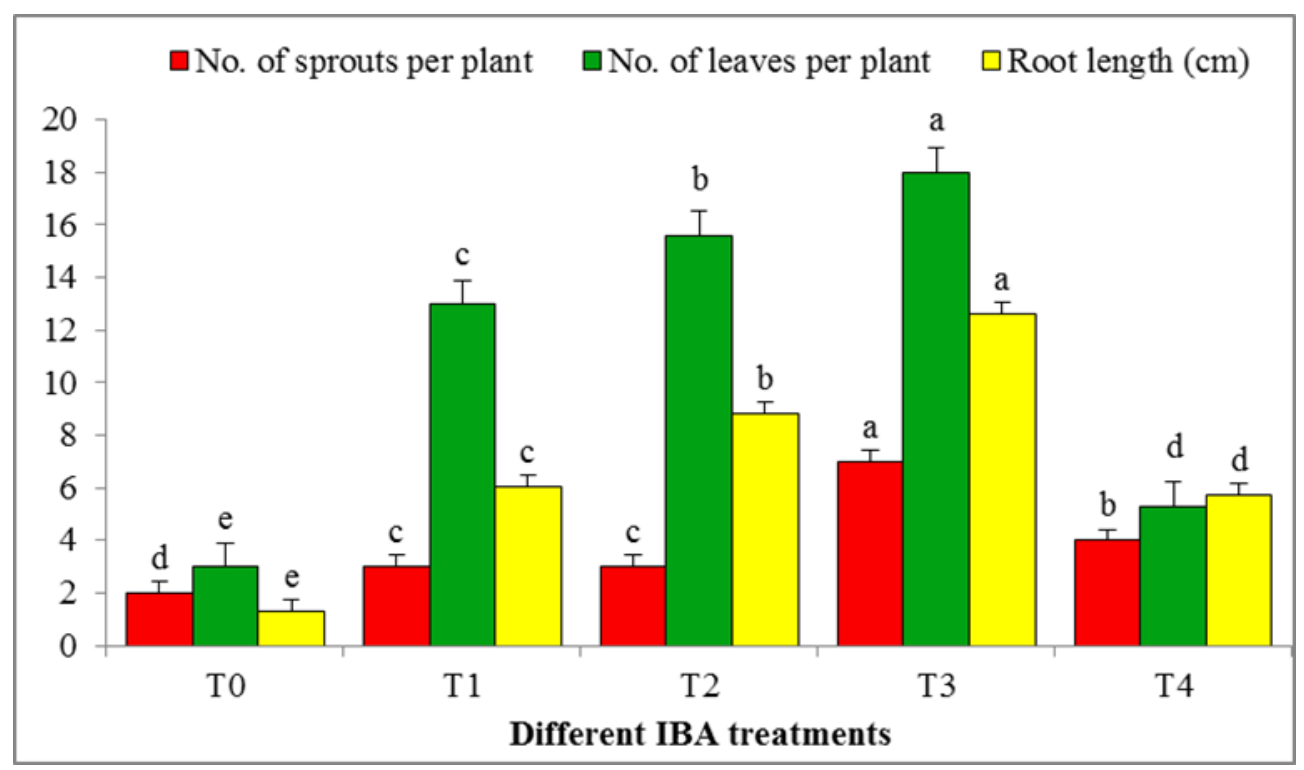

Figure 2. Effect of IBA concentrations on number of sprouts/plant, number of leaves/plant, root length $(\mathrm{cm})$ of Guava cv. Sufeda propagated through air layering

\section{Number of leaves per plant}

The mean value for number of leaves per plant showed that maximum numbers of leaves were observed in T3 (18) as compared to other concentrations, while less number of leaves in control T0 (3) (Figure 2). This result showed that maximum concentration of IBA produced more leaves in Guava air layers. It 
might be because of high root length and more mineral, nutrients such like nitrogen and water availability, which stimulates vegetative growth. Also IBA reduces the level of stress and increase the photosynthetic pigments in vegetative parts such like leaves [10]. Favorable climatic conditions may also play an important role in augmenting the number of leaves per plant. Similarly [17] also reported that large number of leaves (10.55) were recorded in treatment received 2500 PPM of IBA and small number of leaves (6.11) was observed in control treatment. The layer treated with 2500 PPM produced more number of roots and thus absorbed more nutrient which in turn produced more number of leaves.

\section{Root length (cm)}

The mean value of root length as shown in the (Figure 2) showed that maximum root length was attained by $\mathrm{T} 3$ treatment $(12.6 \mathrm{~cm})$, and minimum root length was observed in control T0 $(1.3 \mathrm{~cm})$. This is because maximum concentration of IBA increased root length. That might be attributed that the action of auxin might cause hydrolysis and translocation of nitrogenous substances and carbohydrates at the cellular level in the base of cuttings and resulted in accelerated cell elongation and cell division and thus helps in the formation of root primordial in the place of incision under favorable environmental condition [18, 19]. These results are in conformity with $[\mathbf{1 7}, \mathbf{2 0}, \mathbf{2 1}]$ who observed that application of growth regulators can accelerate the process of rooting in air layering.

\section{Fresh and dry root weight (g)}

The fresh and dry root weight was significantly influenced by application of growth regulators. The higher concentration with T3 (150 PPM) showed comparatively fresh and dry root weight (1.96 g) and (0.70 $\mathrm{g}$ ), whereas it was lowest for fresh and dry root weight was observed in control treatment T0 (0.05 g) and $(0.02 \mathrm{~g})$ respectively (Figure 3). IBA hormone induces rooting in guava cv. Sufeda is shown in (Figure 4). These results are in agreement with [22] in jackfruit and [23] in litchi. Similar results were reported by [7] in litchi and [24] the highest root weight noticed in the current study may attribute by the fact that optimum concentration of auxin, when applied may encourage the movement of natural auxin and other nutrients in downward direction from leaves and other parts which results in accumulation at the place of incision on the shoot due to which higher fresh and dry root weight is formed. The reason might be due to formation of more number of primary and secondary roots, and more root length when treated with comparatively higher concentration of 150 PPM. Similar results were observed by [7], and [6] in guava, and [25] in pomegranate.

\section{Chlorophyll and carotenoid pigments $(\mu \mathrm{g} / \mathrm{ml})$}

The chlorophyll-A (chl-A), chlorophyll-B (chl-B), total chlorophyll (Tchl) and carotenoid (Car) pigments were significantly influenced by application of growth regulator IBA. The higher concentration of chlorophyll-A (22.31 $\mu \mathrm{g} / \mathrm{ml})$, chlorophyll-B (23.41 $\mu \mathrm{g} / \mathrm{ml})$, total chlorophyll (45.72 $\mu \mathrm{g} / \mathrm{ml})$ and carotenoid $(3.55 \mu \mathrm{g} / \mathrm{ml})$ with $\mathrm{T} 3$ (150 PPM) treatment of IBA, whereas lowest chlorophyll-A (11.9 $\mu \mathrm{g} / \mathrm{ml})$, chlorophyll-B (13.81 $\mu \mathrm{g} / \mathrm{ml})$, total chlorophyll (25.70 $\mu \mathrm{g} / \mathrm{ml})$ and carotenoid $(1.02 \mu \mathrm{g} / \mathrm{ml})$ was observed in control treatment T0 (0.05) respectively (Figure 5). Among the treatments, 150 ppm IBA may be sufficient to increase the chlorophyll content and carotenoid in guava cuttings. This could be due to the fact that auxin delayed leaf abscission and inhibits leaf drop in guava cuttings that may increase the partitioning of photo-assimilate towards the leaves [26]. Furthermore, auxin is also abundant in young leaves, floral organs and developing seeds and fruits. Its concentration is more in young 
and fast growing organs, which decline with age and is affected mostly by external factors, e.g. by light, temperature and other climatic conditions. According to [27] total chlorophyll content in leaves of grape vine stem cuttings enhanced after IBA treatment. Similarly, [28] reported that total leaf chlorophyll content in stem cuttings of three apple cultivars (Starkrimson Delicious,
Golden Delicious and Misket Delicious) were significantly increased by treatment of 2000 and $3000 \mathrm{mg} /$ IBA. On contrary, [29] reported that different concentration and application level of auxin and their interaction significantly affected chlorophyllA, while shows a non-significant effect on chlorophyll-B, total chlorophyll and total carotenoid content of leaf.

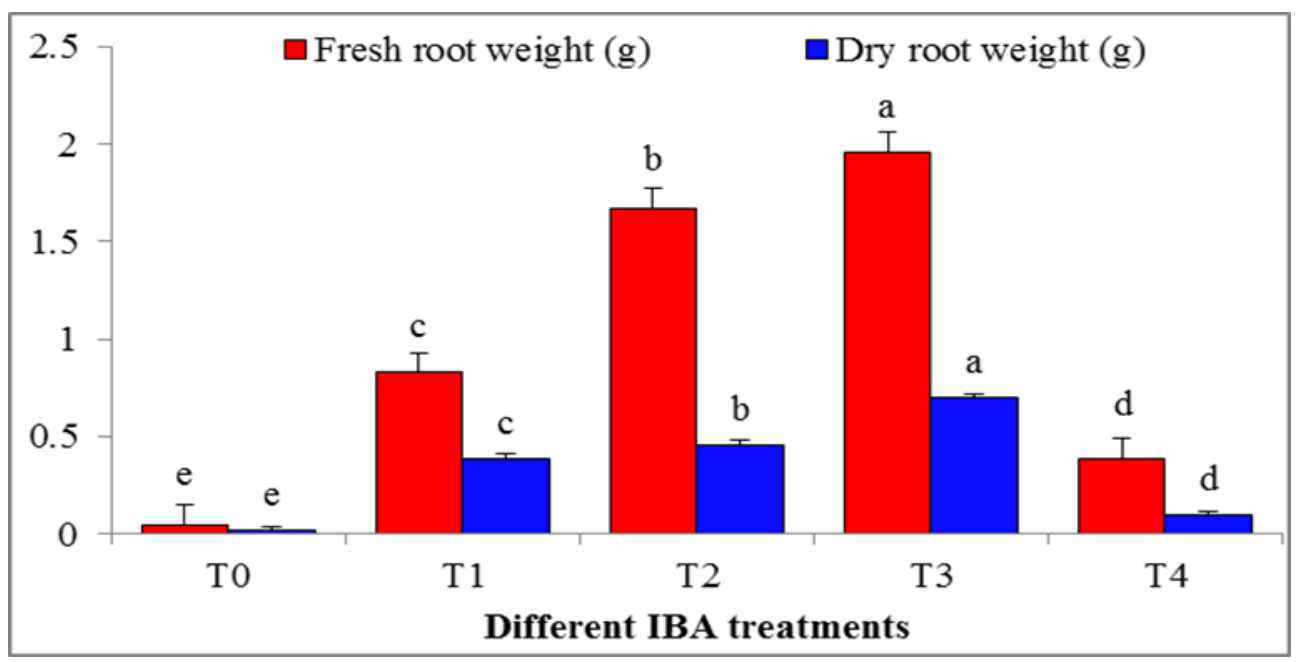

Figure 3. Effect of IBA concentrations on fresh root weight (g) and dry root weight (g) of Guava cv. Sufeda propagated through air layering

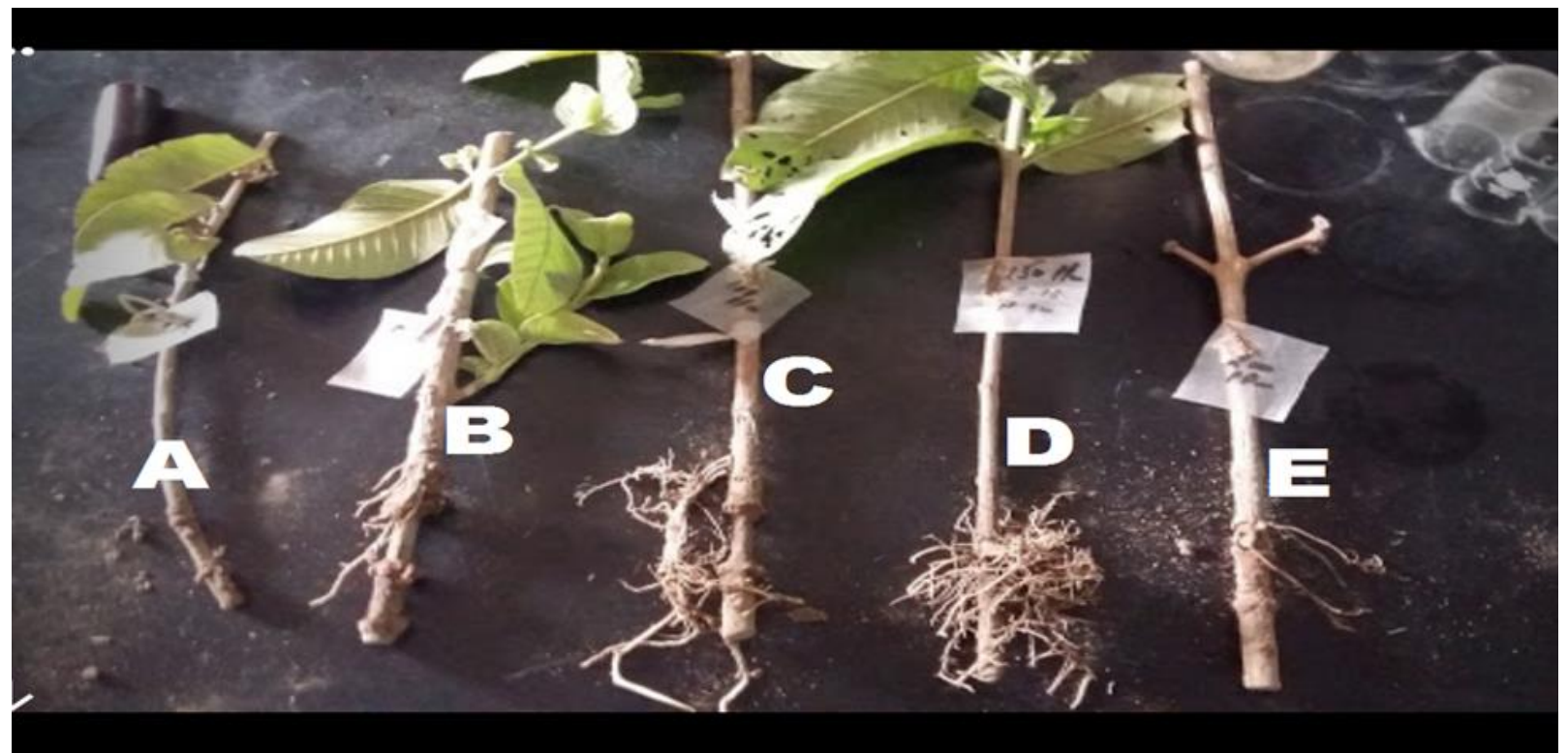

Figure 4. Indolebutyric acid hormone induces rooting in guava cv. Sufeda (A) T0-Control, (B) T1-50 PPM, (C) T2-100 PPM, (D) T3-150 PPM, (E) T4-200 PPM 


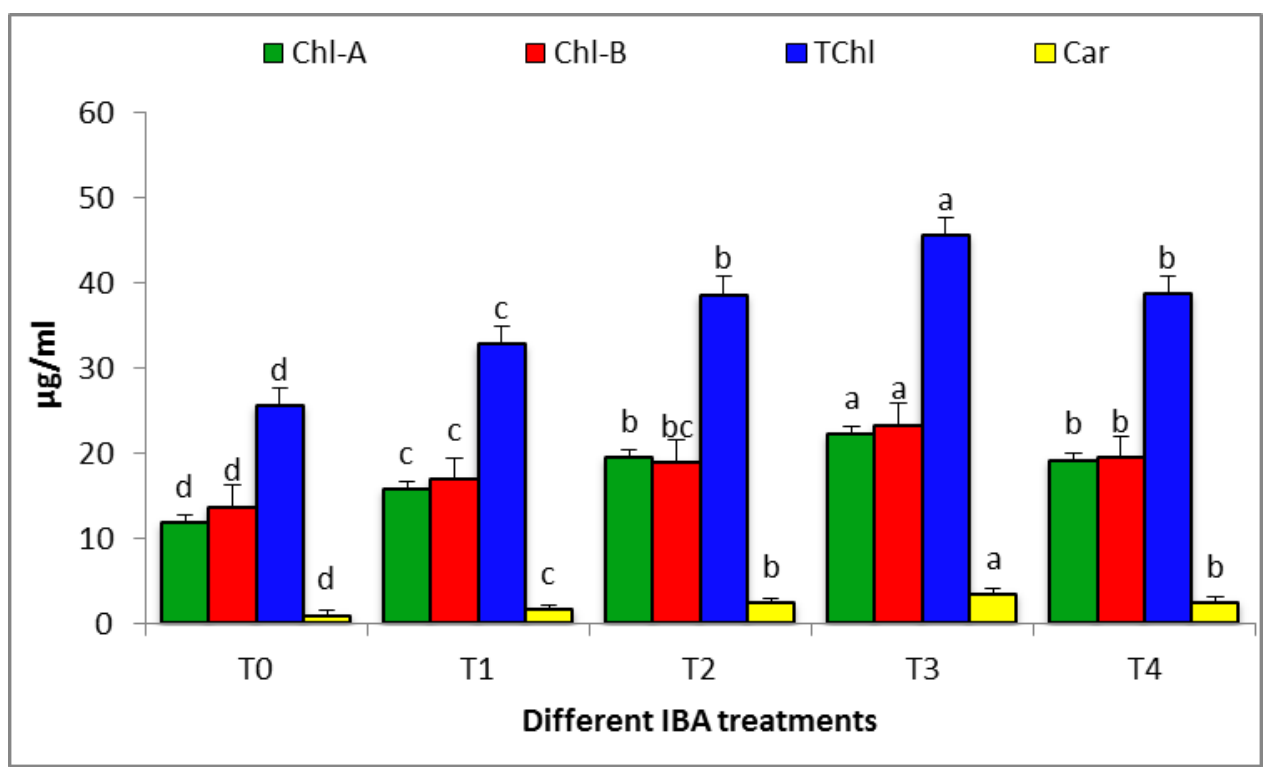

Figure 5. Effect of different IBA concentrations on chlorophyll and carotenoid ( $\mu \mathrm{g} / \mathrm{ml})$ pigments of Guava cv. Sufeda propagated through air layering

\section{Conclusion}

It is concluded from the present study that Guava (Psidium guajava) cv. Sufeda can be successfully propagated through air layering with 150PPM of IBA concentration. Further studies are recommended to check the effects of IBA on fruit quality and production.

\section{Authors' contributions}

Conceived and designed the experiments: $S$ AQ Gilani \& $K$ Shah, Performed the experiments: SAQ Gilani, K Shah \& A Basit, Analyzed the data: A Basit, M Sajid, A S Bano \& G Ara, Contributed materials/ analysis/ tools: I Ahmed, U Shahid, Wrote the paper: S A Q Gilani, K Shah, A Basit \& G Ara.

\section{Acknowledgements}

We would like to thank Tasneem Akhtar (USTC) for her valuable suggestions.

\section{References}

1. Loh C \& Rao A (1989). Clonal propagation of guava (Psidium guajava L.) from seedlings and grafted plants and adventitious shoot formation in vitro. Scientia Horticul 39(1): 31-39.

2. Maqbool M \& Khan D (1973). Propagation of fruit plants, studies on the propagation of guava by stem cuttings. Pak J Agri 4: 177-193.
3. Hartmann HT \& Kester DE (1975). Plant propagation: principles and practices. Prentice-Hall.

4. Cooper WS (1911). Reproduction by layering among conifers. Botanical Gazette 52(5): 369-379.

5. Sileshi G, Mkonda FKAA \& Ajayi OC (2007). Effect of growth media and fertilizer application on biomass allocation and survival of Uapaca kirkiana Mell Arg seedlings. Sci Res and Ess 2(9): 408-415.

6. Tyagi SK (2001). Effect of Growth Regulators on Rooting of Air-Layering of Guava (Psidium Guajava L.) Sardar Guava. JNKVV, Jabalpur.

7. Rymbai H \& Reddy GS (2010). Effect of IBA, time of layering and rooting media on air-layers and plantlets survival under different growing nursery conditions in guava. Indian J of Horticul 67(4): 99-104.

8. Baghel M, Raut U \& Ramteke V (2016). Effect of IBA Concentrations and Time of Air-layering in Guava cv. L-49. Res $J$ of Agri Sci 7(1): 117-120.

9. Shah K, et al. (2017). Dust particles induce stress, reduce various photosynthetic pigments and their derivatives in Ficus benjamina: a landscape plant. Int J Agric Biol 19: 1469-1474. 
10. Shah K, et al. (2018). Impact assessment of leaf pigments in selected landscape plants exposed to roadside dust. Environ Sci and Pollution Res 1-19.

11. Steel R (1997). Analysis of variance I: The one-way classification. Principles and Procedures of Statistics A Biometrical Approach, pp 139-203.

12. Ghosh A, et al. (2017). Efficacy of different levels of IBA and NAA on rooting of Phalsa (Grewia asiatica L.) cuttings. IJCS 5(6): 567-571.

13. Singh K \& Tomar Y (2015). Effect of plant ing time and indole butyric acid levels on rooting of woody cuttings of Phalsa (Grewia asiatica L.). Hort Flora Res Spectrum 4(1): 39-43.

14. Mankar J, Wankhade R \& Bhople S (2009). Effect of some plant growth regulators on rooting and survival of layerage in guava by polybag method. Annals of Plant Physiol 23(2): 192-195.

15. Chandramouli H, Chandregowda $M$ \& Mallikarjuna GA (2003). Influence of growth regulators on the rooting of different types of cuttings in Indian lavender (Bursera pencillata (DC) Eng.). in Proceedings of the National Seminar on New Prospective in Spices, Medicinal and Aromatic Plants.

16. Patil V, et al. (2000). Effects of different growth regulators on rooting of hardwood cuttings of some commercial grape varieties. J of Soils and Crops 10(2): 295297.

17. Rahman N et al. (2000). Effect of different concentrations of IBA on rooting of litchi (Litchi chinensis) in air layering. Pak $J$ of Biol Sci 2000. 3(2): 330-331.

18. Tchoundjeu Z, et al. (2002). Vegetative propagation of Prunus africana: effects of rooting medium, auxin concentrations and leaf area. Agroforestry Syst 54(3): 183192.

19. Singh A, Singh R \& Mittal A (2003). Effect of plant growth regulators on survival rooting and growth characters in long pepper (Piper longum L.).

20. Hackett WP (1988). Donor plant maturation and adventitious root formation. Adv in Plant Sci Seri.

21. Bacarin M, et al. (1994). Rooting of stem cuttings of guava: effect of indole butyric acid on root of guava. Cientifica Jab 22: 71-79.

22. Hatibarua P, Gogoi S \& Mazumder A (1997). Adventitious Rooting in Jack Fruit (Artocarpus heterophyllus Lam.) Air Layers Induced with Etiolation and Rooting Hormones. Annals of Biol 13: 155-160.

23. Sinha R \& Ray S (200). Effect of different growth regulators in air layering of litchi cv. Bombai. Hort J 15(1): 63-67.

24. Ray R, et al. (2001). Effect of PGR and coloured wrapping material on propagation of litchi cv. Purbi. Haryana $J$ of Horti Sci 30(3/4): 170-172.

25. Bhosale V, et al. (2014). Response of different media and PGR's on rooting and survival of airlayers in pomegranate (Punica granatum L.) cv. Sindhuri. Annals of Horti 7(1): 73-77.

26. Devi J, et al. (2016). Role of Auxin and Dates of Planting on Growth of Cutting Raised Plantlets of Phalsa (Grewia asiatica L.). The Bioscan 11(1): 535-537.

27. Kaur S, et al. (2002). Chemical induction of physiological changes during adventitious root formation and bud break in grapevine cuttings. Plant Growth Regul 37(1): 63-68.

28. Sıvacı A \& Yalçın İ (2006). Determination of Physiological Changes in Related to Effects of Exogenous Indole-Butyric-Acid and Callus Formation in Some Kinds of Apple (Malus sylvestris Miller) Stem Cuttings. Fen Bilimleri Dergisi 27(2).

29. Omar TJ \& Khudhur SA (2015). Effect of NAA and IAA on stem cuttings of Dalbergia sissoo (Roxb). J of Biol and Life Sci 6(2): 208-220. 